\title{
Heat loss from hot water flowing in a copper pipe insulated using air enclosed with a PVC pipe
}

\section{A. Albayani, M. Mirmanto*, S. Syahrul}

Teknik Mesin Fakultas Teknik Universitas Mataram, Jln. Majapahit No. 62 Mataram Nusa Tenggara Barat Kode Pos : 83125, Telp. (0370) 636087; 636126; ext 128 Fax (0370) 636087.

*Email: m.mirmanto@unram.ac.id

\section{ARTICLE INFO}

Article History:

Received : 12 June 2017

Accepted : 30 July 2017

Available online: 1 January 2018

Keywords:

Heat loss

Copper pipe

Air

PVC pipe

Critical diameter theory

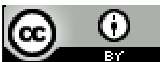

\section{ABSTRACT}

This paper presents investigations of heat loss from hot water flowing in an insulated copper pipe. Investigations were performed to know the heat loss from a copper pipe insulated using air enclosed with a PVC pipe. The fluid temperature used was kept at approximately $75^{\circ} \mathrm{C}$ in the entrance and its mass flow rate was around $12 \mathrm{~g} / \mathrm{s}$. The nominal copper pipe diameter was $6.35 \mathrm{~mm}$; while the diameters of the PVC pipe were ranging from $12.7 \mathrm{~mm}$ to $5.08 \mathrm{~mm}$. The length of the test section was approximately $3000 \mathrm{~mm}$. The results show that the biggest heat loss is found using the bare copper pipe. When the copper pipe is insulated using air enclosed with a PVC pipe, the heat loss decreases with the increased PVC pipe diameters. The trend of the heat loss agrees with the critical insulation diameter theory.

\section{INTRODUCTION}

Industries need devices to support their works, operations and productions. For example in oil industries, a piping with a good insulation is usually required. Flowing oil from one place to another place at very low ambient temperature needs a pipe with a very good insulation, otherwise, it is frozen and jammed.

Many studies reported investigations on pipe insulations using several different materials, Hiller (2005), Ljubenko et al. (2011), Xiao et al. (2014). Meanwhile, insulations made of polyolefin or polyethylene, with thicknesses of either $1 / 2$ inch or $3 / 4$ inch were also investigated by Hiller (2005). He used the polyolefin because its thermal conductivity was low; it was $0.02 \mathrm{Btu} / \mathrm{hr} \mathrm{ft} F$, which was suitable as a thermal insulation. Heat loss from hot water pipe lines had been investigated intensively; see Ljubenko et al. (2011). They suggested that the pipe lines should be covered using polyurethanes. Furthermore, previous researchers, Xiao et al. (2014) suggested that to reduce the heat loss to the ambient, the pipe lines should be covered using materials that had a low thermal conductivity such as PPR (Polypropylene Random polymer) or plastics that had lower thermal conductivities. The PPR has a thermal conductivity of $0.24 \mathrm{~W} / \mathrm{m}^{\circ} \mathrm{C}$. More recent, insulations made of biomass composite were studied by Abdulkareem et al. (2016). They revealed that biomass composite insulations had thermal conductivities ranging from 0.0074 to $0.0127 \mathrm{~W} / \mathrm{m}^{\circ} \mathrm{C}$. Those values are lower than air thermal conductivity $\left(0.024 \mathrm{~W} / \mathrm{m}^{\circ} \mathrm{C}\right)$. Nevertheless, making biomass insulation is not simple and it should be made in an industry, otherwise, the uniform thickness cannot be obtained. Also, producing biomass insulation can be not as cheap as air insulation. 
In hotels, many insulated pipes are used, material had been also reported in a published

Table 1 Properties of the PVC pipe

\begin{tabular}{lcc}
\hline \multicolumn{1}{c}{ Property } & Rigid PVC & Flexible PVC \\
\hline Density $\left(\mathrm{g} / \mathrm{cm}^{3}\right)$ & $1.3-1.45$ & $1.1-1.35$ \\
Thermal conductivity $(\mathrm{W} / \mathrm{m} \mathrm{K})$ & $0.14-0.28$ & $0.14-0.17$ \\
Yield strength (psi) & $4500-8700$ & $1450-3600$ \\
Young's modulus (psi) & 490,000 & \\
Flexural strength (psi) & 10,500 & \\
Compression strength (psi) & 9500 & \\
Coefficient of thermal expansion (linear) & $5 \times 10^{-5}$ & \\
$\left(\mathrm{~mm} / \mathrm{mm}^{\circ} \mathrm{C}\right)$ & $65-100$ & Not recommended \\
Vicat B $\left({ }^{\circ} \mathrm{C}\right)$ & $10^{16}$ & $10^{12}-10^{15}$ \\
Resistivity $(\Omega \mathrm{m})$ & $10^{13}-10^{14}$ & $10^{12}$ \\
Surface resistivity $(\Omega)$ & & \\
\hline
\end{tabular}

e.g. hot water piping, HVAC (heating venting and air conditioning) piping. However, all insulations used for those purposes have been standardized and they have certain thermal conductivities. Usually their thermal conductivities should be as low as possible. The common materials used as insulation have thermal conductivities ranging from 0.026 to $0.065 \mathrm{~W} / \mathrm{m}^{\circ} \mathrm{C}$, see Morvay and Gvozdenac (2008). However, the material that has lower thermal conductivities becomes priority materials for insulations. In this study, the insulations that are examined are air enclosed by a PVC (Polyvinyl chloride) pipe. The reason for this is because of its prize. The air is free; however, the PVC price is still acceptable.

The fundamental purpose of the use of insulations is to prevent the heat leakage. However, in industry the use of insulation does not only consider the heat loss but also the insulation prices. Therefore, the cheapest price and the lowest thermal conductivity of insulation become famous targets for engineers. The price of the PVC pipe depends on the standard, thickness, and the diameter of the pipe. Nevertheless, in this study the PVC pipes used are commercial PVC pipes with the cheapest price. The properties of the PVC pipe are shown in Table 1.

Air as insulation is used in some cases, e.g. double glass windows, double walls, hollow bricks, hot water storage, and thermos. For these purposes, the air is used because it is free and has a very low thermal conductivity. In general, the air thermal conductivities are ranging from 0.012 to $0.052 \mathrm{~W} / \mathrm{m}^{\circ} \mathrm{C}$ at temperatures ranging from $-150^{\circ} \mathrm{C}$ to $400^{\circ} \mathrm{C}$. An investigation of air as insulation literatur, Sadauskiene et al. (2009). They performed experiments using a vertical air gap apparatus. The gaps were varied from $3 \mathrm{~mm}$ to 20 $\mathrm{mm}$. They concluded that increasing the air gap increased the heat transfer rate. They presented their findings in a graph correlating the air gap and the measured air thermal conductivity.

The aim of this study is to know the effect of air gap as insulation on the heat loss to the ambient. However, the air gap is provided in a concentric pipe not as in the cavity between two plates.

\section{EXPERIMENTAL SET UP}

Experiments were conducted using a test rig as shown in Figure 1. Cold water was drawn from a reservoir and flowed using a centrifugal pump model 16WZR-16 Booster HA. The flow rate of water was adjusted using a valve and measured using a calibrated flow meter model FLR1012ST-D with an uncertainty of $\pm 0.5 \mathrm{~g} / \mathrm{s}$. After leaving the flow meter, the water was heated up utilizing a gas heater and an electric heater to ascend the water temperature reaching of approximately $80^{\circ} \mathrm{C}$ at the pipe entrance. In the pipe, the water released the heat to the environment through the copper pipe wall (Case A) and through the copper pipe and PVC pipe walls (Case B, C and D). Detail dimensions of the pipe/tube are presented in Table 2. All temperatures were measured using K-type thermocouples with an uncertainty of $\pm 0.1^{\circ} \mathrm{C}$ obtained from calibration. The positions of the thermocouple can be seen in Figure 1.

Heat transfer in this study is heat loss from the water to the environment trough the tube wall. 


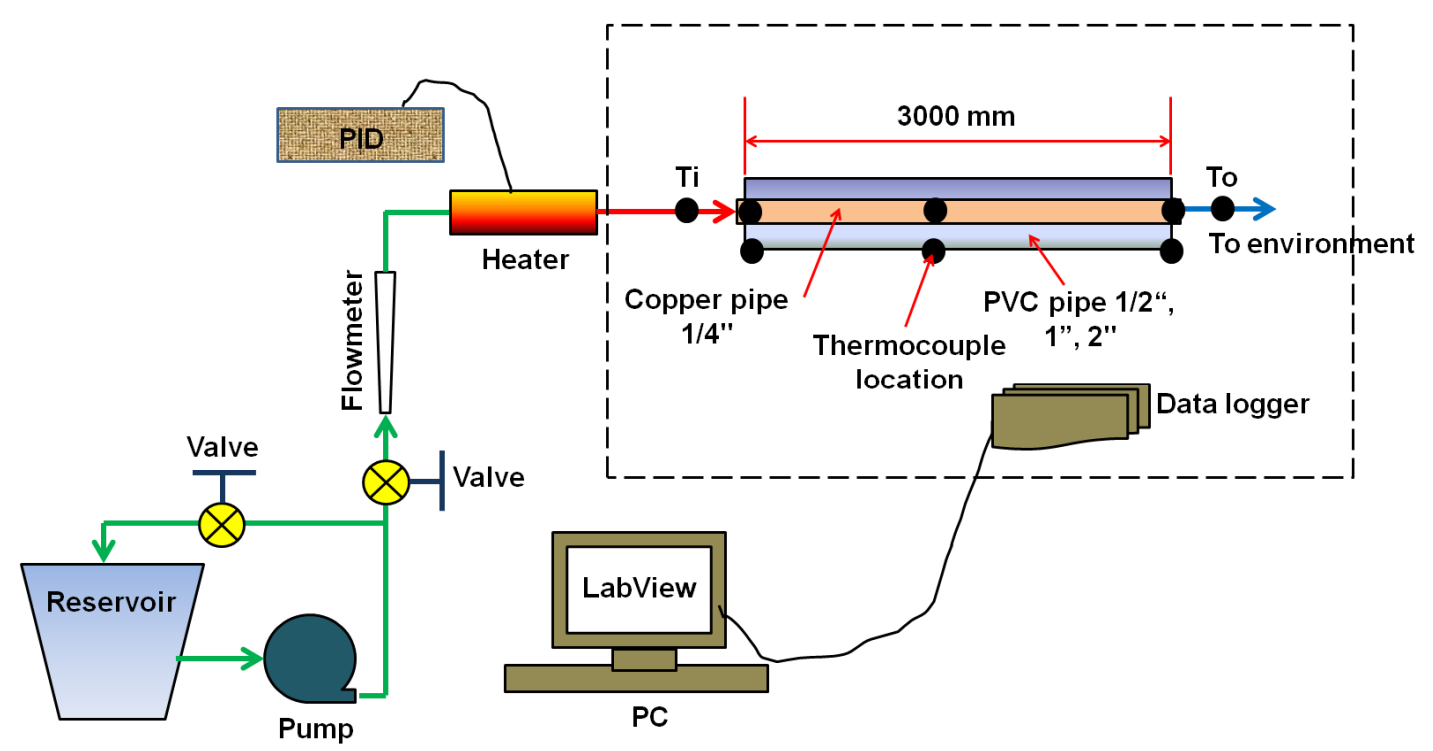

Figure 1. Schematic diagram of the test rig

Hence there is an energy balance that can be estimated as written in Holman (1997):

$$
\begin{aligned}
& q_{i}=q_{\text {loss }} \\
& q_{i}=\dot{m} c_{p}\left(T_{i}-T_{o}\right) \\
& q_{\text {loss }}=h_{o} A\left(T_{w}-T_{a}\right)
\end{aligned}
$$

where $q_{i}$ represents the heat input $(\mathrm{W}), q_{\text {loss }}$ is the heat loss from the fluid (water) to the environment (W), $\dot{m}$ is the mass flow rate $(\mathrm{kg} / \mathrm{s}), c_{p}$ is the specific heat $\left(\mathrm{J} / \mathrm{kg}^{\circ} \mathrm{C}\right), T_{i}$ and $T_{o}$ are the inlet and outlet temperatures $\left({ }^{\circ} \mathrm{C}\right)$. A represents the heat transfer area $\left(\mathrm{m}^{2}\right)$, while $T_{w}$ and $T_{a}$ are the wall and ambient temperatures $\left({ }^{\circ} \mathrm{C}\right)$. In this study, $T_{i}, T_{o}, T_{w}$, and $T_{a}$ are measured directly, hence $q_{i}$ can be obtained. For the Case B, C, and D, $T_{w}$ is located on the outer wall of the PVC tube. Equation (2) was also used by previous researchers, e.g. Ljubenko et al. [2]. If there is no heat loss to other directions, then Equation (2) is the same as Equation (3) and $h_{o}$ can be determined. $h_{o}$ resulted from those two equations is the experimental free heat transfer coefficient, which is expressed as, Holman (1997):

$$
h_{o}=\frac{\dot{m} c_{p}\left(T_{i}-T_{o}\right)}{A\left(T_{w}-T_{a}\right)}
$$

Table 2. Dimension of the tubes and Cases, $L=$ $3000 \mathrm{~mm}$

\begin{tabular}{llll}
\hline Case & Single/Double & \multicolumn{2}{c}{$\begin{array}{c}\text { Nominal diameter } \\
(\mathrm{mm})\end{array}$} \\
\cline { 3 - 4 } & & Copper & PVC \\
\hline A & Single & 6.35 & \\
B & Double & 6.35 & 12.7 \\
C & Double & 6.35 & 25.4 \\
D & Double & 6.35 & 50.8 \\
\hline
\end{tabular}

\section{RESULTS AND DISCUSSION}

Experiments were performed at an inlet temperature of around $75^{\circ} \mathrm{C}$ measured at the entrance of the test section. The results are presented in the form of graphs. Before presenting the heat loss, temperature differences $\Delta T=\left(T_{i}\right.$ $T_{o}$ ) need to be existed for all cases, see Figure 2 . The temperature differences are used to estimate the heat loss and all temperatures are recorded for about 3000 seconds. From Figure 2, it can be seen that Case $A$ results in higher temperature differences, however, the temperature difference fluctuates with a big margin. This is due to the environment and random error effects. 
When a PVC pipe is existed to cover the copper pipe, the difference temperatures decrease and their fluctuation margins are lesser. This means that the PVC pipe can reduce the heat loss and even the fluctuation of the temperature difference. Increasing the diameter of the PVC pipe decreases the temperature differences.
Consequently, the heat loss decreases with an increase in the PVC pipe diameter, see Figure 3. Nevertheless, the study of this subject is still very limited, or even there is no investigation on the use of air enclosed using a PVC pipe as isolation. Note: in Figure 3, when the temperature differences are indicating close to zero degree, the heaters are not on yet.

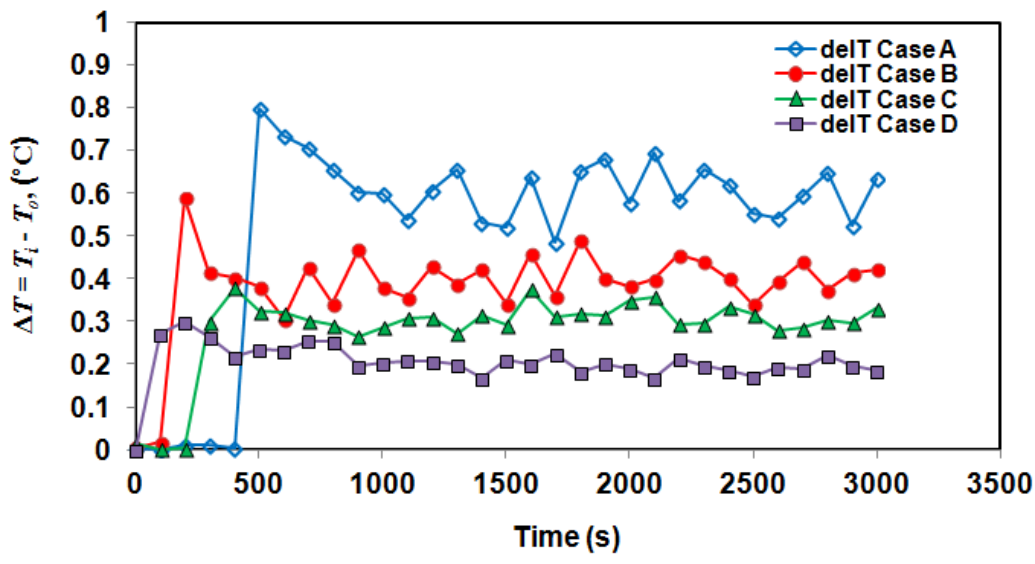

Figure 2. Temperature difference, $\Delta T=T_{i}-T_{o}$ for all cases at the same inlet temperature of $75^{\circ} \mathrm{C}$ and mass flow rate of $12 \mathrm{~g} / \mathrm{s}$. delT $=\Delta T$

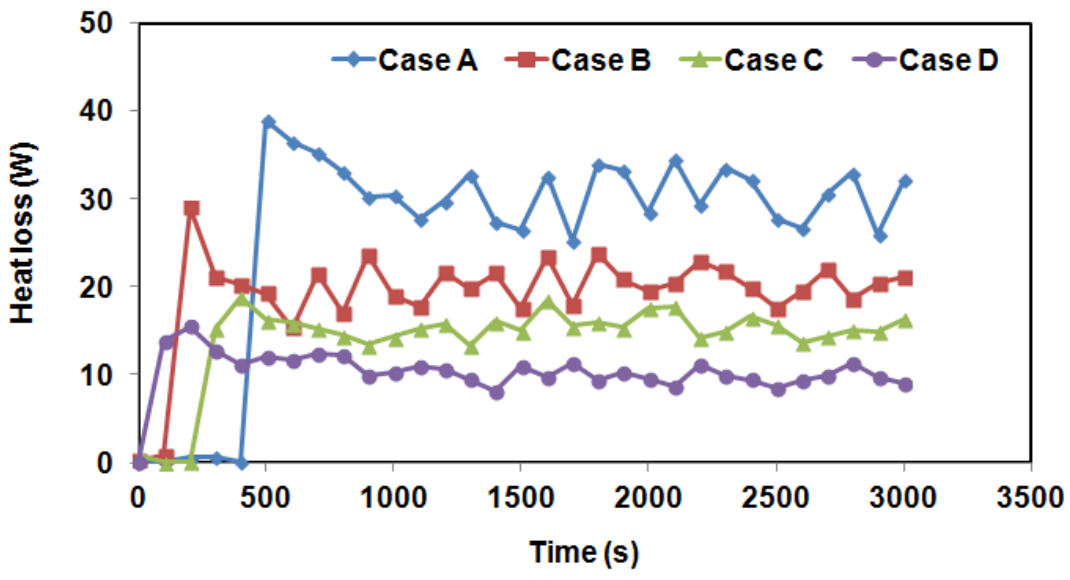

Figure 3. Heat losses to the environment for all cases at the same inlet temperature of $75^{\circ} \mathrm{C}$ and mass flow rate of $12 \mathrm{~g} / \mathrm{s}$ 

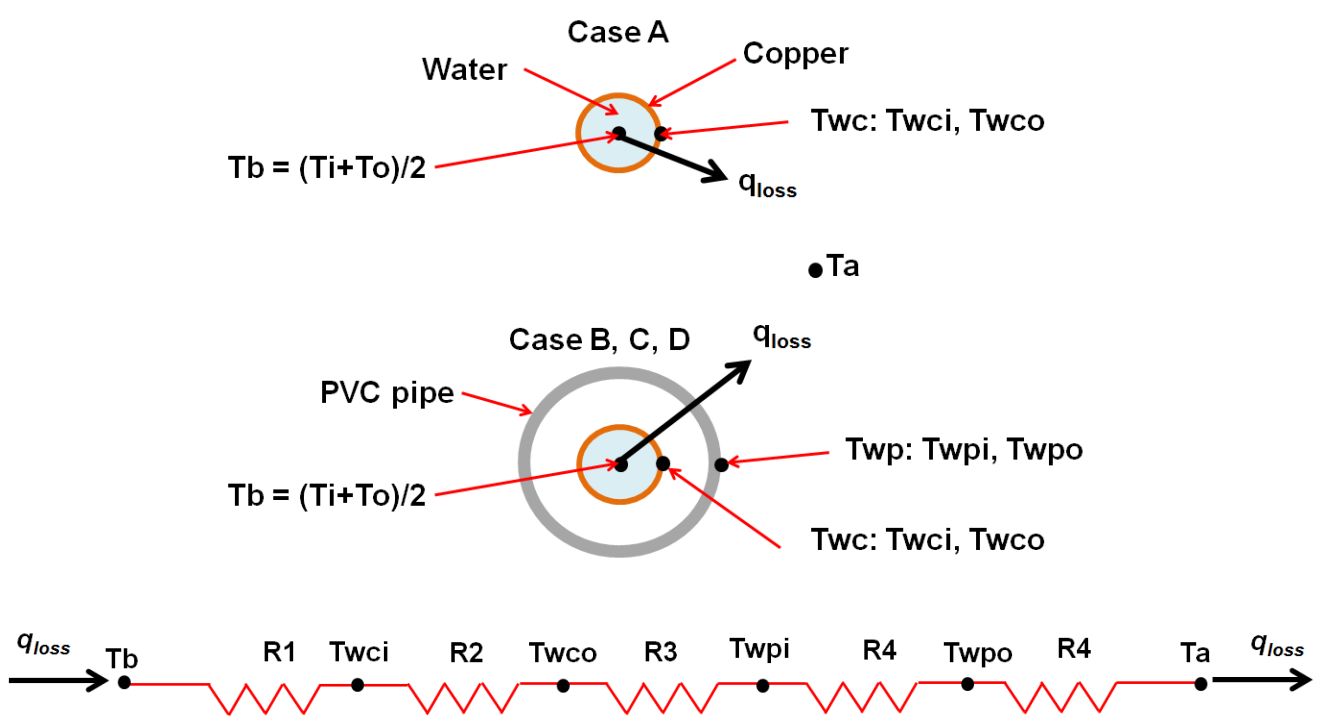

Figure 4. Schematic diagram of heat flows from the water to the environment through pipe walls and thermal circuit

However, according to the Engineering tool box, the heat loss from copper pipes with a nominal diameter of $1 / 2$ ", is approximately $40 \mathrm{~W} / \mathrm{m}$. Increasing the diameter of the copper pipe raises the heat loss. Meanwhile, the experimental heat loss from a copper pipe with a diameter of $1 / 4$ " is around $10 \mathrm{~W} / \mathrm{m}$. So following the Engineering Tool heat loss from a copper pipe with a diameter $1 / 2^{\prime \prime}$ or more.

To determine experimental free heat transfer coefficients, an illustration of heat flow is described as follows, see Figure 4. Due to measurements of $T_{\text {wco }}$ and $T_{\text {wpo }}$, heat loss, can be estimated and given by equation (5) and (6). Equation (5) for the

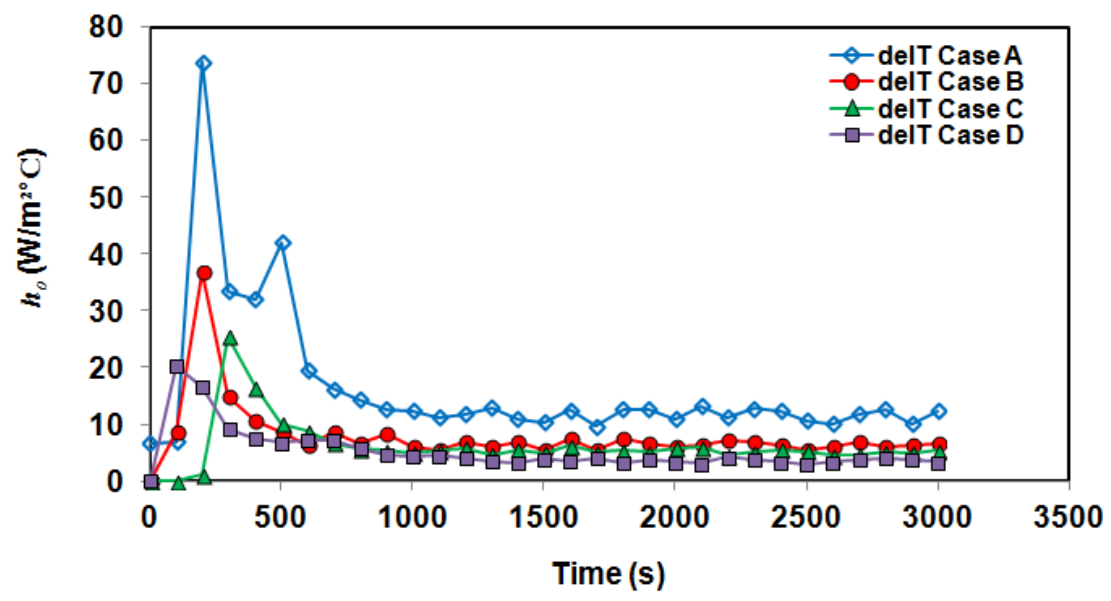

Figure 5. Experimental free heat transfer coefficients for all cases at the same inlet temperature of $75^{\circ} \mathrm{C}$ and mass flow rate of $12 \mathrm{~g} / \mathrm{s}$

Box, the heat loss obtained in this study is on the right track, because the heat loss is lower than the
Case A, and equation (6) for the Case B, C and D, can be estimated, Holman (1997): 


$$
\begin{aligned}
& q_{\text {loss }}=h_{o} A\left(T_{w c o}-T_{a}\right) \\
& q_{\text {loss }}=h_{o} A\left(T_{w p o}-T_{a}\right)
\end{aligned}
$$

However, $q_{\text {loss }}$ is the same as $q_{i}$, if the heat

$$
r_{c}=\frac{k}{h_{o}}
$$

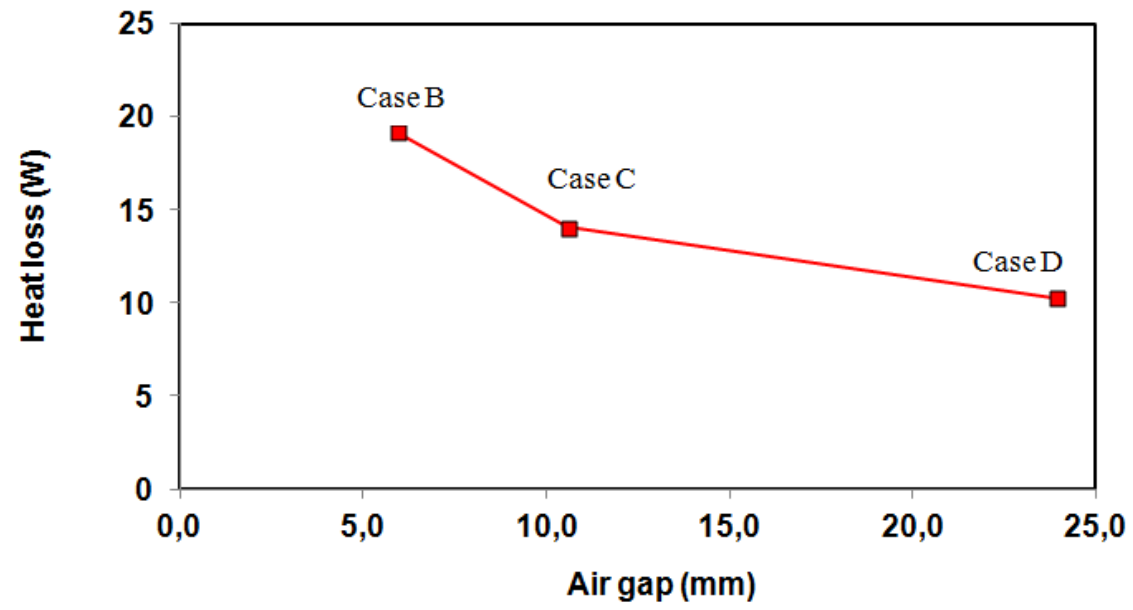

Figure 6. Effect of air gap on the heat loss for cases B, C and D at the same inlet temperature of $75^{\circ} \mathrm{C}$ and mass flow rate of $12 \mathrm{~g} / \mathrm{s}$

loss to the ends of the pipe is neglected. Therefore, using Equation (4), $h_{0}$ can be calculated and the results of the calculation are given in Figure 5.

In Figure 5, from the time 0 to around $500 \mathrm{~s}$, the heat transfer coefficient fluctuates with a big margin, then after $500 \mathrm{~s}$, it starts to be constant. This is because of the increased inlet temperature before the flow or the temperatures reach the steady condition. At the 0 to $500 \mathrm{~s}$, the inlet temperature is increasing because the heaters are presently turned on. At this time period, the condition is still transient. However, this finding is still in the range of the free heat transfer coefficient obtained by previous researchers; see Lee, et al. (2013). They found that their experimental free heat transfer coefficients were ranging from 2 to 10 $\mathrm{W} / \mathrm{m}^{2 \circ} \mathrm{C}$. This was also found by Mirmanto dkk (2016a, 2016b, 2016c), Mirmanto dkk (2017).

The relationship between the air gap and the heat loss is presented here, see Figure 6. As the gap increases, the heat loss decreases. It means, in these experimental conditions, the thicker insulation is the better. The trend of $q_{\text {loss }}$ with the air gap should be checked using a critical radius. The critical radius can be obtained in Holman (1997) and is expressed as: radius of the insulation is less than the critical radius, increasing the insulation thickness gives the increased heat loss. Let us choose Case D with the biggest outer radius. The thermal conductivity of the PVC is approximately 0.0455 $\mathrm{W} / \mathrm{m}^{\circ} \mathrm{C}$, while the free convection heat transfer coefficient of the air determined from the experiments is around $5.2 \mathrm{~W} / \mathrm{m}^{2 \circ} \mathrm{C}$, hence the critical radius is $0.011 \mathrm{~m}$. Meanwhile, the outer radius of the PVC pipe is $0.03 \mathrm{~m}$; therefore, the outer radius is bigger than the critical radius. Following the critical radius theory, see equation (5), increasing the insulation thickness decreases the heat loss. It means that the trend of heat loss in Figure 6 is right.

\section{CONCLUSION}

Experiments to investigate the heat loss from hot water flowing in a copper pipe have been performed. Hot water was used as the working fluid. The mass flow rate of the water used was around $12 \mathrm{~g} / \mathrm{s}$ and the inlet temperature of $75^{\circ} \mathrm{C}$ was kept constant at the entrance of the test section. From the experimental data and analysis, some concusions may be drawn as follows:

1. The biggest heat loss occurs in the bare copper pipe.

2. As the diameter of the PVC pipe increases the heat loss decreases. 
3. The trend of the heat loss with the increase in air gap agrees with the insulation critical diameter theory.

4. The air gap can be used as a good insulation material.

\section{ACKNOWLEDGEMENTS}

The authors would like to acknowledge the Mechanical Engineering Department for the facility.

\section{NOMENCLATURE}

A Heat transfer area $\left(\mathrm{m}^{2}\right)$

$c_{p} \quad$ Specific heat $\left(\mathrm{J} / \mathrm{kg}^{\circ} \mathrm{C}\right)$

delT Delta T

HVAC Heating ventilating and air conditioning

$h_{0} \quad$ Free convection heat transfer coefficient $\left(\mathrm{W} / \mathrm{m}^{2 \circ} \mathrm{C}\right)$

$k \quad$ Thermal conductivity $\left(\mathrm{W} / \mathrm{m}^{\circ} \mathrm{C}\right)$

$L \quad$ Length of the test section (m)

$\dot{m} \quad$ Mass flow rate $(\mathrm{kg} / \mathrm{s})$

PVC Polyvinyl chloride

$q_{\text {loss }} \quad$ Heat loss (W)

$R \quad$ Thermal resistance $\left({ }^{\circ} \mathrm{C} / \mathrm{W}\right)$

$r_{c} \quad$ Critical radius $(\mathrm{m})$

$T \quad$ Temperature $\left({ }^{\circ} \mathrm{C}\right)$

$T_{a} \quad$ Ambient temperature $\left({ }^{\circ} \mathrm{C}\right)$

$T_{b} \quad$ Bulk temperature, $T_{b}=\left(T_{i}+T_{o}\right) / 2,\left({ }^{\circ} \mathrm{C}\right)$

$T_{\text {wc }} \quad$ Copper wall temperature $\left({ }^{\circ} \mathrm{C}\right)$

$T_{w p} \quad$ PVC pipe wall temperature $\left({ }^{\circ} \mathrm{C}\right)$

$\Delta T \quad$ Temperature difference $\left({ }^{\circ} \mathrm{C}\right)$

\section{Subscript:}

i Inlet, inner

o Outlet, outer

\section{REFERENCES}

Abdulkareem S., Ogunmodede S., Aweda J.O., Abdulrahim A.T., Ajiboye T.K., Ahmed I.I., Adebisi J.A., 2016, Investigation of thermal insulation properties of biomass composites. International Journal of Technology, 6, 989999.Hiller C., 2005, Hot water distribution system research - Phase I, Pier Final Project Report, Applied Energy Technology, California.

Holman J.P., 1997, Heat Transfer. 8th Edition, McGraw-Hill Inc., USA. http://www. engineeringtoolbox .com/copperpipe-heat-loss-d 19.html.

Ljubenko A., Zager A.P.M., 2011, Effects of hotwater-pipeline renovation in a district heating system, Journal Mechanical Engineering, 57, 834-842.

Lee S., Nagomi M., Yamaguchi S., Kurabuchi T., Ohira N., 2013, Evaluation of heat transfer coefficients in various air-conditioning modes by using thermal manikin, 13th Conference of International Building Performance Simulation Association, August 26-28, Chambery, France.

Mirmanto M., Sayoga I.M.A, Zulkarnain Z., 2016a, Pengaruh debit terhadap unjuk kerja alat penukar kalor dan penurunan suhu ruangan, Dinamika Teknik Mesin, 6(1), 1-7.

Mirmanto M., Sulistyowati E.D., Okariawan I.D.K., $2016 \mathrm{~b}$, Effect of radiator type on dryer room temperature distribution and heat transfer rate, JP Journal of Heat and Mass Transfer, 13(4), 511-532.

Mirmanto M., Sulistyowati E.D., Okariawan I.D.K., 2016c, Effect of radiator position and mass flux on the dryer room heat transfer rate, Results in Physics, 6, 139-144.

Mirmanto M., Syahrul S., Sulistyowati E.D., Okariawan I.D.K., 2017, Effect of inlet temperature and ventilation on heat transfer rate and water content removal of red chilies, Journal of Mechanical Science and Technology, 31(3), 1531-1537.

Morvay Z.K., Gvozdenac D.D., 2008, Applied industrial energy and environmental management, First Edition, Part III, John Wiley \& Sons Ltd, The Atrium, Southern Gate, Chichester, West Sussex, PO19 8SQ, United Kingdom.

Sadauskiene J., Buska A., Burlingis A., Bliudzius R., Gailius A., 2009, The effect of vertical air gaps to thermal transmittance of horizontal thermal insulating layer, Journal Civil Engineering and Management, 15(3), 309315.

Xiao S., Luo Q., Li G., 2014, Analysis on transmission heat loss in hot water system of residential building, Journal Energy and Power Engineering, 8, 1913-1917. 